\title{
SISTEM DAN MEKANISE PENYUSUNAN ANGGARAN PENERIMAAN DAN PENGELUARAN DANA PADA YAYASAN BINA UMMAT KELAPA DUA
}

\author{
F.X. Kurniawan Tjakrawala ${ }^{1}$ dan Nurainun Bangun ${ }^{2}$ \\ ${ }^{1}$ Prodi Pendidikan Profesi Akuntan, Universitas Tarumanagara \\ Surel: kurmiawant@fe.untar.ac.id \\ ${ }^{2}$ Prodi S1 Akuntansi, Universitas Tarumanagara \\ Surel: nurainunb@fe.untar.ac.id
}

\begin{abstract}
The purpose of community service activities (PKM) in the first period of 2020 is to provide counseling using learning modules that provide knowledge about revenue and expenditure systems and budgets in non-profit organizations, which in this case is a foundation-shaped organization, the Bina Ummat Kelapa Dua Foundation. The problem is a lack of understanding and budgeting for revenue and expenditure of foundation funds for planning and controlling donor funds. The foundation acknowledges that the financial reporting system has not been systematic, so donors have not been able to listen to financial accountability reports in a comprehensive manner. The target of this PKM is the management along with a number of teachers and administrative staff of the Bina Ummat Kelapa Dua Foundation in order to find solutions to their problems in the form of training activities that will use modules which are one of the outputs of this PKM. The methods used are lecture, question-and-answer methods, and practice module material. This PKM involved students from the Accounting Study Program of FEB UNTAR. Students try to add insight into the real facts of problems that exist in the community environment, as well as efforts to involve students in activities to offer real solutions to problems that are in accordance with the scientific field. The results has conducted in tune with its purposes. The result is also accompanied with mandatory outputs in the form of scientific publications and additional outputs too, namely learning modules which has been submitted to PKM partner.
\end{abstract}

Keywords: PKM, budget, system, foundation, non-profit

\begin{abstract}
ABSTRAK
Tujuan dari aktivitas pengabdian kepada masyarakat (PKM) pada periode I (satu) 2020 ini adalah mengadakan penyuluhan dengan menggunakan modul belajar yang memberikan pengetahuan mengenai sistem dan mekanisme penyusunan anggaran penerimaan dan pengeluaran dana pada organisasi nirlaba, yang dalam hal ini adalah organisasi berbentuk yayasan yaitu Yayasan Bina Ummat Kelapa Dua. Permasalahan yang dialami oleh pihak yayasan adalah kurangnya pemahaman mengenai sistem dan mekanisme penyusunan anggaran penerimaan dan pengeluaran dana yayasan untuk keperluan perencanaan dan pengendalian dana donatur. Pihak yayasan mengakui bahwa sejauh ini masih belum sistematis dalam sistem pelaporan keuangan, sehingga para donatur belum dapat menyimak laporan pertanggungjawaban keuangan secara komprehensif meskipun dalam format yang sederhana. Target kegiatan yang akan dicapai dalam PKM ini adalah pengurus beserta sejumlah guru dan staf administrasi yang bernaung pada Yayasan Bina Ummat Kelapa Dua agar memperoleh solusi atas permasalahan mereka berupa aktivitas pelatihan yang akan menggunakan modul yang menjadi salah satu luaran dari kegiatan PKM ini. Metode yang dipakai dalam PKM ini adalah metode ceramah, tanya-jawab, dan praktik materi modul. Kegiatan PKM ini juga melibatkan mahasiswa dari Prodi S1 akuntansi FEB UNTAR. Keterlibatan mahasiswa dimaksudkan guna menambah wawasan mengenai fakta riil permasalahan yang ada di lingkunga masyarakat, serta upaya melibatkan makasiswa dalam aktivitas pemberian solusi nyata atas permasalahan target yang dihadapi berdasarkan bidang keilmuan yang dikuasai. Hasil kegiatan PKM telah berlangsung sesuai tujuan, dengan luaran wajib berupa publikasi ilmiah dan juga luaran tambahan yaitu modul belajat yang ditujukan kepada mitra PKM.
\end{abstract}

Kata Kunci: PKM, anggaran, sistem, yayasan, nirlaba

\section{PENDAHULUAN}

Yayasan Bina Ummat Kelapa Dua berlokasi di Jl. Kano 1 RT 001/RW 09 Kelapa Dua, Tangerang-Banten, 15810. Lokasi tersebut berjarak sekitar $30 \mathrm{KM}$ dari Universitas Tarumanagara Kampus 1, dengan waktu tempuh normal antara 40 sampai dengan 50 menit bila 
menggunakan kendaraan pribadi atau taksi online melewati jalur tol Merak-Jakarta atau jalur tol Jakarta-Tangerang. Yayasan ini mulai beraktivitas pada tahun 2009, dengan akte pendirian oleh Notaris Amien Ruati, S.H., M.Kn. pada tahun 2008. Yayasan Bina Ummat Kelapa Dua merupakan organisasi nirlaba yang memiliki unit kerja bernama Raudhatul Athfal Nurul Jannah dengan fokus kegiatannya ditujukan dalam bidang pendidikan khususnya kepada anak usia dini (PAUD) dan menyelenggarakan taman pengajian Al Quran anak-anak dari keluarga dengan latar belakang ekonomi yang lemah. Oleh karena tidak ingin memberatkan para wali murid yang mayoritas darti golongan tidak mampum nenyebabkan pendanaan yayasan mayoritas dari donasi

Sebagaimana sering dialami oleh organisasi berbentuk yayasan dengan skala kecil adalah terkait dengan aspek administrasi dana donatur. Ibu Atikah Noor-bendahara Yayasanmengungkapkan kepada Tim Pengusul bahwa dana operasional yayasan diperoleh dari para donatur tetap maupun dari pihak lain yang bersimpati dengan kegiatan yayasan selama ini. Ibu Atikah Noor menyatakan bahwa pengurus yayasan memiliki keterbatasan dalam pengetahuan maupun ketrampilan untuk mengadministrasikan anggaran dana masuk maupun keluar serta pelaporan pertaggungjawaban penggunaan dana donatur yayasan secara sistematis. Beliau mengakui bahwa kondisi sumberdaya manusia yang menjadi pengurus yayasan tidak ada yang berlatar belakang pendidikan ekonomi ataupun administrasi niaga. Semua pengurus termasuk guru berasal dari sekolah tinggi agama, sedangkan staf administrasi rata-rata hanya berpendidikan Madrasah aliyah. Beliau mengungkapkan bahwa mayoritas pengurus tidak paham bagaimana mekanisme penyusunan anggaran dana masuk dan keluar yayasan untuk program kerja maupun terkait dengan tujuan pelaporan pertanggugjawaban kepada para donatur.

Seiring dengan perkembangan yayasan, maka pengurus merasakan perlunya mekanisme penilaian pencapaian riil dari pendapatan dan belanja yayasan dengan mampu menyusun anggaran dana masuk dan keluar yayasan. Hal ini, sebagaimana diakui oleh Ibu Atikah Noor relatif merepotkan pihak pengurus yayasan apabila terdapat donatur yang meminta laporan penggunaan dana secara lengkap dan sistematis. Demikian sejumlah fakta yang didapatkan dari hasil survey oleh Tim Pengusul. Faktor keterbatasan waktu dari personil Tim PKM tidak memungkinkan untuk mengidentifikasi semua permasalahan yang dialami oleh Mitra PKM/Abdimas. Setelah berbincang dengan bendahara Yayasan, tim PKM memprioritaskan pada aspek penyusunan anggaran penerimaan dan pengeluaran dana bagi pihak yayasan yang menjadi topik $\mathrm{PKM}$ /Abdimas untuk periode ini. Sebagai hasil dari perbincangan dengan pihak pengurus Yayasan Bina Ummat Kelapa Dua, untuk periode Abdimas ini, Tim PKM mendapatkan sejumlah fakta yang merupakan identifikasi dari permasalahan yang dihadapi oleh pengurus dan juga staf yayasan yaitu: bahwa pihak yayasan mengalami kesulitan berkenaan dengan mekanisme penyususnan anggaran penerimaan dan belanja yayasan. Aspek administrasi anggaran untuk perencanaan maupun pengendalian dana yayasan relatif nenberatkan pengurus yayasan yang tidak paham ilmu ekonomi perusahaan. Minimnya pengetahuan mengenai mekanisme penyusunan anggran yang memadai bagi organisasi nirlaba berjenis yayasan tentu perlu diberikan solusinya melalui kegiatan PKM ini. Oleh karena itu telah disepakati oleh tim PKM dan mitra yaitu Yayasan Bina Ummat Kelapa Dua, bahwa perlu adanya pembahasan dan pemahaman mengenai bagaimana sistem dan mekanisme penyusunan anggaran penerimaan dan pengeluaran dana untuk unit kerja yayasan yaitu raudhatul athfal Nurul Jannah.

Secara umum, organisasi dimaknai sebagai kumpulan orang yang bekerjasama demi tujuan tertentu yang dapat bersifat jangka pendek maupun jangka panjang. Demi mencapai tujuan tersebut, suatu organisasi perlu mengadakan unit kerja yang bertanggungjawab terhadap keberhasilan suatu tugas atau fungsi. Hal ini tentunya memunculkan aspek akuntabilitas pada unit lain dengan level yang lebih tinggi dalam pengambilan keputusan. Umumnya setiap organisasi 
formal pada hakikatnya menerapkan jalur instruksi dan pertanggungjawaban, antara level yang lebih tinggi dan level yang lebih rendah. (Granof, Khumawala, Calabrese, Smith, 2016 dan Penabulu, 2013). Organisasi nirlaba lebih berorientasi pada visi/misinya, dan memiliki tujuan utama melaksanakan aktivitas publik tanpa berorientasi laba/komersil. Organisasi nirlaba dapat mencakup bidang, terkait dengan isu-isu sosial, derma, lingkungan, bantuan kemanusiaan, konservasi, pendidikan, kesenian, dan lain-lain. Kendati tidak berorientasi pada laba, namun jika terdapat laba dari kegiatannya maka akan digunakan kembali dalam beragai aktivitas guna mencukung visi dan misinya. Salah satu yang termasuk dalam organisasi nirlaba adalah yayasan (Penabulu, 2013). Menurut Prasetya (2014) dan sebagaimana juga diamanatkan dalam UU No. 16 tahun 2001 bahwa yayasan merupakan subyek hukum yang berujud badan hukum dengan pemisahan harta dan diperuntukkan guna mencapai tujuan tertentu dibidang sosial, keagamaan, dan kemanusiaan. Aktivitas pengelola yayasan semata mengumpulkan donasi dari para dermawan, kemudian dialokasikan kepada badan-badan kegiatan sosial, seperti panti-panti asuhan, rumah sakit dan sejenisnya. Pengurus yayasan bahkan tidak terlibat dalam pengelolaan badan pendidikan, panti, rumah sakit, dan lain-lain. Pengelolaan yayasan terkait dengan prinsip tata kelola yang baik, perlu check and balance dalam kepengurusan tersebut (Leblanc, 2016 dan Prasetya, 2014). Bahkan UU No. 16 tahun 2001 melarang pembina, pengawas, dan pengurus yayasan untuk merangkap jabatan.

Bagi manajemen, anggaran menjadi sarana dalam melakukan aktivitas perencanaan dan pengawasan untuk mencapai tujuan organisasi. Keefektifan anggaran tergantung pada SDM organisasi dalam melakukan aktivitas perencanaan serta pengawasan Anggaran dapat diartikan juga sebagai rencana penerimaan dan pengeluaran yang diharapkan akan terjadi selama satu atau beberapa periode mendatang. Umumnya anggaran dibuat untuk masa satu tahun dan menjadi awal dari siklus pengelolaan keuangan. Dalam organisasi nirlaba, rencana berupa penyusunan usulan biaya. Jika usulan tersebut telah disetujui oleh pihak yayasan, maka organisasi nirlaba akan menerima hibah yang digunakan untuk program kerja. Dalam rentang pelaksanaan program itulah terjadi aneka transaksi keuangan, maka pencatatan akuntansi pun langsung bekerja yang kemudian menghasilkan laporan keuangan. (Penabulu, 2013).

Berdasarkan aspek sumber dana, PSAK No. 45 (IAI, 2011) telah mengelompokan penerimaan organisasi nirlaba menadi dua yaitu sumbangan dan non-sumbagan. Penerimaan sumbangan/hibah/donasi merupakan penerimaan organisasi dari donatur berdasarkan usulan rencana program kerja tanpa didahului deengan aktivitas menghasilkan barang dan/atau jasa terlebih dahulu kepada donatur, yang dapat berasal dari pemerintah; CSR dari perusahaan; donatur internasional; komunitas masyarakat. Jika organisasi nirlaba perlu mengadakan barang dan/jasa kepada donatur sebelum mendapatkan dana, maka penerimaan ini tergolong dalam nonsumbangan, yang dapat berupa hasil usaha komersial di bawah yayasan (dividen dari penyertaan modal, SHU koperasi yang didirikan oleh yayasan); hasil investasi (bunga bank, bunga deposito, penjualan aktiva tetap yayasan); kegiatan fundrising (hasil dari penyelenggaraan pameran, penjualan buku, penyewaan aktiva tetap, kegiatan fasilitasi diluar program). Berdasarkan aspek terikat-tidaknya dengan batasan tertentu, PSAK No. 45 (IAI, 2011) telah mengklasifikasi penerimaan organisasi nirlaba menjadi tiga yaitu penerimaan tidak terikat; terikat sementar; serta terikat permanen. Penerimaan tidak terikat merupakan jenis penerimaan dari donatur yang memberikan kebebasan penuh kepada manajemen organisasi dalam mengalokasikan penggunaan dana. Penerimaan terikat sementara merupakan jenis penerimaan dari donatur dengan batasan tertentu berupa waktu ataupun kebutuhan pembiayaan kegiaya tertentu saja, dan umumnya berlangsung dalam perjanjian kesepakatan tertentu. Penerimaan terikat permanen merupakan jenis penerimaan dari donatur dengan batasan yang bersifat mutlak dimana nilai tidak berubah dan 
biasanya yang boleh dipergunakan hanyalah nilai lebih atau hasil dari penggunaan sumber dana/sumber daya.

Setiap organisasi perlu membuat keputusan ekonomi yang akan berpengaruhi terhadap kondisi keuangannya. Kinerja maupun kondisi ekonomi menjadi informasi bagi para pemangku kepentingan dan juga bagi pembuat keputusan ekonomi. Bagi pihak-pihak yang awan tentang akuntansi, maka akuntansi dapat diartikan sebagai semua aktivitas keuanga yang akanmengjasilkan dokumen ekonomisehingga dapat digunakan oleh pembuat keputusan maupun semua pemangku kepentingan. (Penabulu, 2013; Carmichael, Whittington, Graham, 2012). Pada hakikatnya pemahaman tentang akuntansi akan lebih efektif bila menggunakan pendekatan sistem. Pendekatan sistem ini berguna untuk menguraikan sistem dari aspek tujuan, proses dan struktur. Pemahaman yang memadai atas struktur dan proses dari sistem akan mampu menjelaskan tercapai tidaknya tujuan. Sistem akuntansi dan keuangan terpisah berdasarkan tugas dan peran. Bagi kalangan awam, sistem akuntansi sangat terkait bagian pembukuan. Adapun sistem keuangan terkait dengan peran bagian keuangan. Guna membangun sistem akuntansi dan keuangan dalam suatu organisasi, diperlukan pemahaman terhadap struktur organisasi. Sistem akuntansi dan keuangan mencakup sejumlah prosedur yang mengatur rangkaian kegiatan untuk tujuan tertentu. Setiap prosedur meliputi kebijakan, alur dokumen serta uraian kegiatan, yang akan saling terkait sesuai tujuan utama sistem. (Copley, 2015; Gross, McCarthy, Shelmon, 2012; Penabulu, 2013).

Tim pelaksana PKM menyajikan solusi atas permasalahan yang berkaitan dengan sistem pelaporan keuangan yang dialami oleh pihak Yayasan Bina Ummat Kelapa Dua dengan menyusun Modul belajar yang juga akan menjadi materi pada saat pelatihan di lokasi. Adapun modul yang akan diberikan kepada mitra yaitu: modul sistem dan mekanisme penyusunan anggaran penerimaan dan pengeluaran dana organisasi nirlaba. Modul Sistem dan Mekanisme Penyusunan Anggaran Peneri,aam dan Pengeluaran Dana Organisasi Nirlaba akan memuat hal-hal sebagai berikut: Konsep dasar anggaran (pengertian anggaranm, tujuan anggaran, kegunaan aggaran, resiko anggaran, prinsip-prinsip anggaran ); Fungsi dan macam anggaran (fungsi manajemen dalam anggaran, macam anggaran); Aspek peran dan strategi dalam penyusunan anggaran (pihak-pihak yang berperan dalam penyusunan anggaran, pilihan strategi penyusunan anggaran); Penyusunan anggaran organisasi nirlaba (penetapan periode anggaran, penetapan rencana penerimaan dan pengeluaran, penyusunan anggaran, penyusunan arus kas anggaran, penyusunan laporan realisasi anggaran organisasi nirlaba).

\section{METODE PELAKSANAAN PKM}

Kegiatan PKM/Abdimas ini terselenggara denga bersandar pada SPK dari Ketua LPPM Untar No.660-Int-KLPPM-Untar/V/2020, merupakan kegiatan ilmiah dengan mekanisme sistematis yang mencakup tahap perencanaan abdimas, tahap pelaksanaan abdimas, serta tahap pelaporan hasil abdimas. Kelancaran pada setiap tahapan akan sangat menentukan kelanjutan dari tahapan berikutnya. Koordinasi antar personil tim pengusul sangat dibutuhkan demi keberhasilan kegiatan PKM/Abdimas ini. Kegiatan ini berlangsung selama 2 (dua) hari yaitu dimulai dengan acara pembukaan, pembagian modul, penjelasan isi modul, yang meliputi materi sistem dan mekanisme penyusunan anggaran penerimaa dan pengeluaran dana organisasi nirlaba.

Metode yang dipakai dalam PKM/Abdimas ini adalah metode penjelasan/ceramah, tanya-jawab dan praktek materi modul belajar mengenai sistem dan mekanisme penyusunan anggaran penerimaan dan pengeluaran dana organisasi nirlaba yang berbentuk yayasan. Hal ini dilakukan untuk memberi solusi atas permasalahan mitra yaitu Yayasan Bina Ummat Kelapa Dua. Solusi 
yang ditawarkan kepada mitra berupa pelatihan singkat mengenai sistem dan mekanisme penyusunan anggaran penerimaan dan pengeluaran dana organisasi nirlaba kepada pengurus inti, staf administrasi, dan juga guru. Materi disajikan kepada mitra, baik dalam bentuk handout maupun hardcopy modul belajar.

Pada awalnya pihak mitra yang mengundang Tim PKM ini untuk membantu mitra karena ada kesulitan dan ketidaktahuan dalam menghitung amggaran. Tim PKM adalah tim yang telah memperoleh sertifikasi dosen, sehingga setiap semester sudah sewajibnya melakukan Tri Dharma Perguruan Tinggi, salah satunya adalah kegiatan Pengabdian kepada Masyarakat (PKM)/Abdimas. Kegiatan PKM yang telah dilakukan sejauh ini adalah kegiatan yang sesuai dengan spesialisasi keahlian masing-masing.Tim PKM terdiri dari dua orang dosen tetap pada FEB UNTAR yang meliputi satu orang ketua dan satu orang anggota. Tim ini juga melibatkan satu orang mahasiswa dari program studi S1-Akuntansi FEB UNTAR.

\section{HASIL DAN PEMBAHASAN}

Target yang dituju dalam PKM ini adalah pengurus yayasan staf dan juga guru, agar dapat memahami akan pentingnya sistem dan mekanisme penyusunan anggaran penerimaan dan pengeluaran dana organisasi nirlaba bagi pengurus Yayasan Bina Ummat Kelapa Dua. Kegiatan ini dikuti oleh 22 orangm yang berlangsung selama dua hari yaitu pada hari Kamis dan Jum'at tanggal 2 dan 3 April 2020 pada pukul 9.00 s/d 11.30 WIB. Aktivitas PKM ini dilakukan dalam satu rangkaian waktu kegiatan yang terdomumentasikan dalam logbook sebagaimana disajikan pada Tabel 1. Adapun sejumlah foto kegiatan PKM dapat diamati pada Gambar 1.

Tabel 1 Tabulasi Kegiatan PKM

\begin{tabular}{|c|c|c|c|}
\hline $\begin{array}{l}\text { Tahapan } \\
\text { Pelaksanaan } \\
\text { PKM } \\
\end{array}$ & Tanggal & Kegiatan & Lokasi \\
\hline $\begin{array}{l}\text { Tahap } \\
\text { Perencanaan }\end{array}$ & $\begin{array}{l}\text { 06-Jan-2020 } \\
\text { s/d } \\
\text { 17-Jan-2020 } \\
\end{array}$ & $\begin{array}{l}\text { Menerima undangan dari mitra, } \\
\text { survey pendahuluan, identifikasi } \\
\text { masalah; studi literatur yang relevan }\end{array}$ & $\begin{array}{l}\text { Yayasan Bina Ummat Kelapa } \\
\text { Dua; FEB Untar }\end{array}$ \\
\hline $\begin{array}{l}\text { Tahap } \\
\text { Perencanaan }\end{array}$ & $\begin{array}{l}\text { 20-Jan-2020 } \\
\text { s/d } \\
\text { 14-Feb-2020 }\end{array}$ & $\begin{array}{l}\text { Menyusun proposal PKM beserta } \\
\text { dokumen pendukung }\end{array}$ & FEB Untar \\
\hline $\begin{array}{l}\text { Tahap } \\
\text { Perencanaan }\end{array}$ & 17-Feb-2020 & $\begin{array}{l}\text { Proposal PKM periode-1 diajukan ke } \\
\text { LPPM UNTAR }\end{array}$ & LPPM Untar \\
\hline $\begin{array}{l}\text { Tahap } \\
\text { Pelaksanaan }\end{array}$ & $\begin{array}{l}\text { 18-Feb-2020 } \\
\text { s/d } \\
\text { 30-Mar-2020 }\end{array}$ & $\begin{array}{l}\text { Pembuatan modul belajar yang } \\
\text { relevan dengan permasalahan yang } \\
\text { dialami oleh mitra PKM }\end{array}$ & FEB Untar \\
\hline $\begin{array}{l}\text { Tahap } \\
\text { Pelaksanaan }\end{array}$ & $\begin{array}{l}\text { 2-Apr-2020 } \\
\text { s/d } \\
\text { 3-Apr-2020 }\end{array}$ & $\begin{array}{l}\text { Pelaksanaan PKM di lokasi mitra } \\
\text { berupa kegiatan penyuluhan dan juga } \\
\text { penyerahan modul belajar kepada } \\
\text { mitra PKM }\end{array}$ & $\begin{array}{l}\text { Yayasan Bina Ummat Kelapa } \\
\text { Dua (Note: Pada saat kegiatan } \\
\text { PKM ini belum pemprov } \\
\text { Tangerang belum menerapkan } \\
\text { PSBB yang pertama) }\end{array}$ \\
\hline $\begin{array}{l}\text { Tahap } \\
\text { Pelaporan }\end{array}$ & $\begin{array}{l}\text { Mei-2020 } \\
\text { s/d } \\
\text { Juli-2020 }\end{array}$ & $\begin{array}{l}\text { Pembuatan Laporan Kegiatan PKM } \\
\text { dan persiapan untuk kegiatan monev; } \\
\text { Pembuatan artikel ilmiah (draft) }\end{array}$ & WFH/secara daring \\
\hline $\begin{array}{l}\text { Tahap } \\
\text { Pelaporan }\end{array}$ & 05 -Agst-2020 & $\begin{array}{l}\text { Pengiriman email Form Monitoring \& } \\
\text { Evaluasi; Logbook; Laporan } \\
\text { Kemajuan PKM; Luaran Wajib }\end{array}$ & LPPM secara daring \\
\hline $\begin{array}{l}\text { Tahap } \\
\text { Pelaporan }\end{array}$ & 28-Agst-2020 & $\begin{array}{l}\text { Pengumuman hasil monev oleh LPPM } \\
\text { kepada tim PKM }\end{array}$ & WFH/secara daring \\
\hline $\begin{array}{l}\text { Tahap } \\
\text { Pelaporan }\end{array}$ & 07-Sep-2020 & $\begin{array}{l}\text { Pengumuman pelaporan tahap akhir } \\
\text { oleh LPPM kepada tim PKM }\end{array}$ & WFH/secara daring \\
\hline
\end{tabular}




\begin{tabular}{lclc}
\hline \begin{tabular}{c} 
Tahapan \\
Pelaksanaan \\
\multicolumn{1}{c}{ PKM }
\end{tabular} & Tanggal & \multicolumn{1}{c}{ Kegiatan } & \multicolumn{1}{c}{ Lokasi } \\
\hline $\begin{array}{l}\text { Tahap } \\
\text { Pelaporan }\end{array}$ & $12-$ Sep-2020 & $\begin{array}{l}\text { Pengiriman laporan tahap akhir, } \\
\text { logbook, luaran wajib, serta laporan } \\
\text { keuangan }\end{array}$ & LPPM secara daring \\
\hline
\end{tabular}
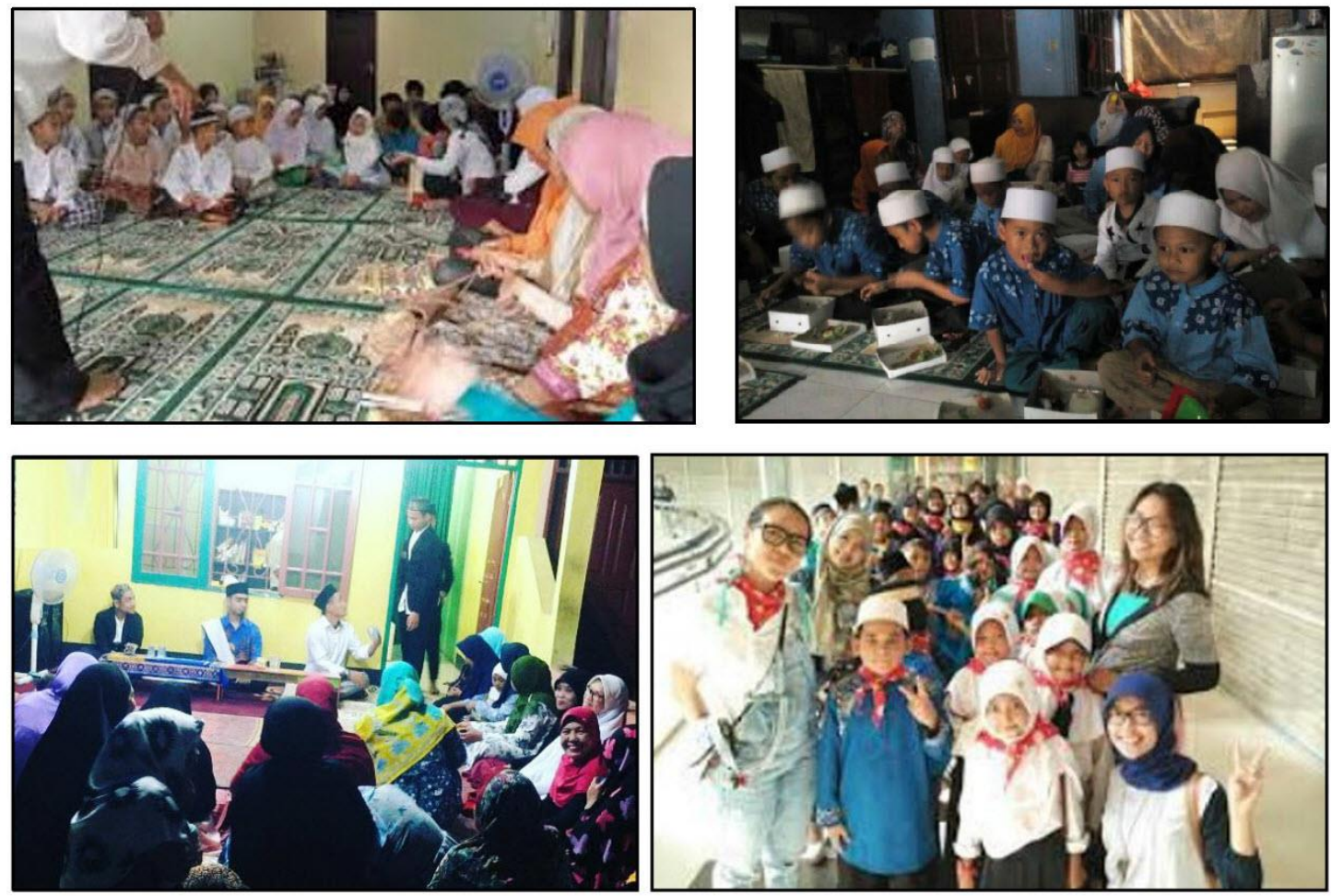

Gambar 1. Foto-Foto Kegiatan PKM

(Sumber: Tim PKM, 2020)

Mayoritas peserta mampu memahami materi modul, yang terindikasi dari tanggapan dan pertanyaan dari peserta mengenai materi modul pada saat penyuluha berlangsung. Pencapaian target ini diharapkan menjadi solusi akan permasalahan mereka terkait dengan sistem dan mekanisme penyusunan anggaran penerimaan dan pegeluaran dana organisasi nirlaba, khususnya yang berbentuk yayasan yang tidak memiliki akuntabilitas publik. Luaran yang dicapai berupa: (a) modul sistem dan mekanisme penyusunan laporan pengelolaan dana organisasi nirlaba yang akan diserahkan kepada pengurus yayasan Bina Ummat Kelapa Dua; (b) publikasi atas kegiatan pelaksanaan Abdimas ini dalam ujud prosiding/jurnal; (c) laporan PKM/Abdimas yang ditujukan kepada LPPM UNTAR, dan juga diserahkan kepada Perpustakaan FEB UNTAR.

\section{KESIMPULAN DAN SARAN}

Pelatihan Sistem dan Mekanisme Penyusunan Anggaran Penerimaan dan Pengeluaran Dana Organisasi Nirlaba "Raudhatul Athfal - Nurul Jannah" pada Yayasan "Bina Ummat Kelapa Dua" telah berlangsung lancar. Peserta kegiatan penyuluhan sangat bersemangat dengan kegiatan ini. Hal ini dikarenakan mereka beranggapan bahwa kegiatan PKM ini memberikan bekal pengetahuan dan ketrampilan untuk masa depan mereka, tidak hanya sekedar memberikan barang sumbangan. Pelatihan ini memberikan dampak bagi para pesertanya yang meminta tim PKM untuk mengadakan kegiatan lanjutan, terutama dari segi pengetahuan dan wawasan yang dapat memotivasi secara personal terhadap para pengurus, staf dan guru pada Yayasan Bina Ummat 
Kelapa Dua. Oleh karena Tim PKM pada periode 12020 hanya berfokus pada masalah penganggaran saja, maka dapat dikatakan bahwa masih banyak permasalahan lain yang dapat didiskusikan dengan mitra untuk aktivitas PKM berikutnya. Dengan demikian masih terbuka peluang untuk mengkaji situasi fakta lain yang berlangsung pada Yayasan Bina Ummat Kelapa Dua.

\section{Ucapan Terima Kasih (Acknowledgement)}

Kegiatan PKM oleh tim dapat terselenggara dengan dukungan dari berbagai pihak. Penulis mengucapkan terimakasih kepada Ketua LPPM Untar, bapak Ir. Jap Tji Beng, Ph.D yang berkenan menyetujui pendanaan dari hibah internal Untar; Manajer LPPM bidang PKM, ibu Dr. Ir. Endah Setyaningsih, MT yang telah memproses dan mengawal secara runtut atas usulan hingga laporan akhir kegiatan PKM; Dekan FEB Untar, bapak Dr. Sawidji Widoatmojo, MBA yang telah mengetahui dan menyetujui usulan kegiatan PKM; Ibu Atikah Noor beserta jajaran dan staf Yayasan Bina Ummat Kelapa Dua yang telah berkenan menjadi mitra kegiatan PKM.

\section{REFERENSI}

Carmichael, D.R., Whittington, O.R., Graham, L. (2012). Accountants' handbook volume 2: special inductries and special topics. $12^{\text {th }}$ edition. John Wiley \& Sons, Inc: New Jersey.

Copley, P.A. (2015). Essentials of accounting for governmental and not-for-profit organizations. McGraw-Hill Education: NewYork.

Granof, M.H., Khumawala, S.B., Calabrese, T.D., Smith, D. L. (2016). Government and not-forprofit accounting : concepts and practices. John Wiley \& Sons: New York.

Gross, M.J., McCarthy, J.H., Shelmon, N.E. (2012). Financial and accounting guide for not-forprofit organizations. $8^{\text {th }}$ edition. John Wiley \& Sons, Inc: New Jersey.

Ikatan Akuntan Indonesia. (2011). PSAK 45: pelaporan keuangan entitas nirlaba. DSAK-IAI: Jakarta.

Leblanc, R. (2016). The handbook of board governance: a comprehensive guide for public, private and not for profit board members. John Wiley \& Sons: New Jersey.

Penabulu. (2013). Seri modul pelatihan pengelolaan keuangan organisasi nirlaba: sistem akuntansi dan keuangan. Yayasan Penabulu: Jakarta.

Prasetya, R. (2014). Yayasan dalam teori dan praktek. Sinar Grafika: Jakarta. 